\title{
Perbandingan Efek Sevofluran dengan Halotan terhadap Jumlah Neutrofil
}

\author{
Hafniana, Hasanul Arifin, Nazaruddin Umar \\ Fakultas Kedokteran Universitas Sumatera Utara \\ Departemen Anestesiologi dan Terapi Intensif RSUP Haji Adam Malik Medan
}

\begin{abstract}
Abstrak
Neutrofil berperan penting dalam respons imun nonspesifik. Penurunan nilai neutrofil dapat dipakai sebagai parameter sederhana untuk mengukur tingkat stres dan inflamasi sistemik. Penelitian ini bertujuan mengetahui efek agen inhalasi sevofluran dan halotan terhadap penurunan neutrofil. Penelitian ini merupakan uji klinis dengan acak tersamar buta ganda yang membandingkan efek sevofluran dengan halotan terhadap jumlah neutrofil pada 36 pasien ASA I dan II yang menjalani operasi elektif dengan anestesi umum di RSUP Haji Adam Malik Medan periode September 2016. Pasien dibagi dua kelompok, yaitu kelompok yang mendapat agen inhalasi sevofluran dan kelompok yang mendapat inhalasi halotan. Jumlah neutrofil dihitung pada kedua kelompok pada saat sebelum operasi, setelah induksi, dan 90 menit setelah inhalasi. Jumlah neutrofil pada kedua kelompok tidak mengalami penurunan sebelum operasi dan setelah induksi $(p>0,005)$, namun mengalami penurunan pada 90 menit setelah inhalasi $(p<0,005)$ pada tiap-tiap kelompok, namun uji beda antara kelompok sevofluran dan halotan tidak bermakna pada tiga kali pengukuran. Simpulan, tidak terdapat perbedaan antara sevofluran dan halotan terhadap penurunan jumlah neutrofil.
\end{abstract}

Kata kunci: Halotan, neutrofil, sevofluran

\section{Comparison of Sevoflurane and Halothane Effects on Neutrophil Counts}

\begin{abstract}
Neutrophil has an important role in non-spesific immune responses. The declining value of neutrophil can be used as a parameter to measure the level of stress and systemic inflammation. This study aimed to determine the effects of sevoflurane and halothane inhalation agents on the number of neutrophil. This was a double-blind randomized comparing the effects of sevoflurane and halothane on the number of neutrophil in 36 ASA 1 and II patients underwent elective surgery under general anesthesia at Haji Adam Malik Central General Hospital Medan during September 2016. Patients were divided into two groups: the group that received sevoflurane inhalation and the group that received halothane inhalation. The number of neutrophils was counted in both groups before surgery, after induction, and 90 minutes after inhalation. Both groups did not experience a decrease in neutrophil counts before surgery and after induction ( $p>0.005)$, but suffered a decline in the number of neuthrophils 90 minutes after inhalation ( $p>0.005)$. The difference between the sevoflurane and halothane groups was not meaningful in the three times of measurement. In conclusion, there is no difference between sevoflurane and halothane terms of declined number of neutrophils.
\end{abstract}

Key words: Halothane, neutrophil, sevoflurane

Korespondensi: Hafniana, dr., SpAn, Departemen Anestesiologi dan Terapi Intensif Fakultas Kedokteran Universitas Sumatera Utara/RSUP Haji Adam Malik Medan, Jl. Bunga Lau No. 17, Kemenangan Tani, Medan Tuntungan, Kota Medan Sumatera Uatara 20136, Tlpn (061) 8362080,Email ina.hafni@gmail.com 


\section{Pendahuluan}

Tindakan anestesi dan bedah dapat menekan respons imun seperti alergi, infeksi, dan lainlain. Penurunan respons tubuh ini dapat meningkatkan morbiditas pasien. Penelitian secara in vivo membuktikan bahwa paparan terhadap agen anestesi inhalasi dapat memberikan pengaruh atau perubahan pada sel imun. Efek imunosupresif tersebut bergantung pada dosis dan lama waktu pemberian obat. ${ }^{1,2}$

Penghambatan neutrofil akibat paparan anestesi inhalasi tidak hanya berdampak penekanan kemampuan neutrofil dalam membunuh organisme, tetapi juga menekan respons inflamasi awal. Perubahan sistem tampak pada perubahan fungsi sel makrofag dan monosit. Penelitian secara in vitro dan in vivo menggambarkan penurunan fungsi makrofag akibat paparan anestesi inhalasi. Penelitian lain memperlihatkan penurunan fungsi sel natural killer (NK) setelah paparan halotan dan enfluran. Penurunan fungsi sel NK selama masa perioperatif berkaitan dengan peningkatan risiko kematian pada pasien kanker. Beberapa penelitian telah membuktikan efek penghambatan proliferasi sel limfosit dan penekanan pelepasan sitokin pada sel mononuclear darah perifer/ peripheral blood mononuclear cells (PBMC) yang berdampak pada penurunan kemampuan sel dalam melawan mikro-organisme dan sel tumor. ${ }^{3,4}$

Penelitian lain memperlihatkan bahwa agen inhalasi halotan, enfluran, dan sevofluran menyebabkan penurunan produksi hidrogen peroksida oleh neutrofil sehingga berakibat pada penurunan daya bunuh mikroorganisme. ${ }^{5}$

Pemakaian sevofluran pada pasien tanpa trauma operasi menyebabkan penurunan jumlah neutrofil dalam sirkulasi sekitar $6 \%$ tanpa perubahan jumlah leukosit. ${ }^{6}$

Pasien dengan anestesi umum yang menggunakan halotan dan isofluran pada operasi hip arthroplasry menunjukkan penurunan kemotaksis neutrofil, respiratory burst, dan fungsi bakterisid. ${ }^{7}$

Halotan jarang digunakan di Amerika, namun di Indonesia masih dipergunakan sevofluran yang biayanya lebih mahal bila dibanding dengan halotan.

Dari beberapa penelitian memperlihatkan pengaruh agen inhalasi terhadap perubahan jumlah neutrofil yang berfungsi sebagai fagositosis. Penelitian ini dilakukan bertujuan mengetahui efek agen inhalasi sevofluran dan halotan terhadap penurunan neutrofil.

\section{Subjek dan Metode}

Penelitian ini menggunakan desain uji klinis acak tersamar ganda untuk menilai efek anestesi inhalasi sevofluran dengan halotan terhadap penurunan jumlah neutrofil. Populasi dalam penelitian ini adalah pasien yang menjalani tindakan pembedahan elektif dengan anestesi umum di RSUP H. Adam Malik pada bulan September 2016. Sampel dalam penelitian ini adalah populasi yang telah memenuhi kriteria inklusi dan tidak termasuk eksklusi. Kriteria inklusi penelitian ini adalah pasien berusia 16-55 tahun dengan body mass index (BMI) $20-25 \mathrm{~kg} / \mathrm{m}^{2}$, status fisik American Society of Anesthesiologist (ASA) kelas I-II, hasil pemeriksaan darah rutin dan gambaran darah tepi dalam batas normal. Kriteria eksklusi penelitian ini adalah pasien dengan penyakit keganasan, penyakit infeksi, sepsis, durasi operasi $<90$ menit, menerima transfusi darah sebelum operasi, induksi, menerima inhalasi sampai di bawah 90 menit, perdarahan lebih $15 \%$, menggunakan antibiotik dan obat imunomodulator. Untuk menentukan besar sampel dilakukan perhitungan sesuai dengan penelitian serta mempertimbangkan angka putus uji didapatkan jumlah sampel adalah 36 orang. Sampel yang telah memenuhi kriteria inklusi dan tidak termasuk eksklusi dipuasakan makanan padat 6 jam dan air putih 2 jam sebelum operasi dan tidak mendapat premedikasi. Setelah tiba di ruang tunggu kamar bedah, pasien diperiksa ulang identitas, diagnosis, rencana tindakan pembedahan, dan jalur intravena pastikan aliran lancar. Sampel kemudian dibagi dengan cara randomisasi blok menjadi dua kelompok intervensi yang mendapat perlakuan, yaitu kelompok yang 
Tabel 1 Karakteristik Demografi Subjek

\begin{tabular}{lccc}
\hline \multicolumn{1}{c}{ Karakteristik } & $\begin{array}{c}\text { Kelompok Sevofluran } \\
(\mathbf{n = 1 8})\end{array}$ & $\begin{array}{c}\text { Kelompok Halotan } \\
(\mathbf{n = 1 8})\end{array}$ & $\mathbf{p}$ \\
\hline Jenis kelamin, $\mathrm{n}$ & & & \\
Laki-laki & 9 & 11 & $0,18^{\mathrm{a}}$ \\
Perempuan & 9 & 7 & \\
Usia, rata-rata (SB), tahun & $38,2(16,2)$ & $41,7(14,7)$ & $0,5^{\mathrm{b}}$ \\
Berat badan, rata-rata (SB), kg & $57,9(7,8)$ & $57,4(6,1)$ & $0,8^{\mathrm{b}}$ \\
ASA, n & & & \\
I & 10 & 10 & $0,2^{\mathrm{b}}$ \\
II & 8 & 8 & \\
\hline
\end{tabular}

Keterangan: ${ }^{a}$ Chi square, ${ }^{b}$ T Independent

mendapatkan anestesi inhalasi sevofluran (kelompok A) dan kelompok mendapatkan anestesi inhalasi halotan (kelompok B). Dilakukan pengambilan sampel darah vena pertama sebanyak 2,5-3 mL dan dimasukkan ke dalam tabung vacutainer, dikocok berlahan. Pasien kemudian diberikan sedasi dengan midazolam 0,05 mg/kgBB sampai tercapai keadaan sedasi nondepresi (sedasi ringan), pramedikasi dengan fentanil dosis $2 \mu \mathrm{g} /$ kgBB IV, di-induksi dengan propofol dosis 2 $\mathrm{mg} / \mathrm{kgBB}$ IV dan pelumpuh otot rokuronium bromida 1,2 mg/kgBB dan dilakukan intubasi endotrakeal. Sampel darah vena kedua diambil sebanyak 2,5-3 mL disebut T0. Pemeliharaan anestesi dengan $\mathrm{O}_{2}: \mathrm{N}_{2} \mathrm{O}=50 \%: 50 \%$, dan gas inhalasi sevofluran atau halotan konsentrasi 1 minimal alveolar concentration (MAC) yang mulai dihitung dari menit ke-0 setelah intubasi. Pengambilan sampel darah vena ketiga sebanyak 2,5-3 mL diambil menit ke90 operasi disebut T1. Ketiga sampel darah kemudian dibawa ke laboratorium Patologi Klinik RSUP Haji Adam Malik Medan untuk diperiksa.

\section{Hasil}

Penelitian ini diikuti 36 orang pasien yang memenuhi kriteria inklusi dan eksklusi, ditemukan karakteristik demografi berdasar atas jenis kelamin, usia, berat badan, dan ASA yang tidak berbeda signifikan antara dua kelompok ( $p>0,05$; Tabel 1).

Hasil analisis menggunakan uji-t paired pada kelompok sevofluran menunjukkan tidak terdapat perbedaan bermakna antara neutrofil rata-rata sebelum operasi dengan 0 menit setelah induksi $(p=0,77)$. Terdapat perbedaan bermakna antara neutrofil ratarata sebelum operasi dan 90 menit setelah inhalasi sevofluran ( $\mathrm{p}=0,001$; tabel 2 ).

Hasil uji-t paired pada kelompok halotan menunjukkan tidak terdapat perbedaan bermakna antara neutrofil rata-rata sebelum operasi dan setelah intubasi $(p=0,72)$. Terdapat perbedaan bermakna antara rerata neutrofil sebelum operasi dengan 90 menit setelah inhalasi $(\mathrm{p}=0,001$; Tabel 3$)$.

Hasil analisis menggunakan uji-t paired menunjukkan bahwa tidak ditemukan

Tabel 2 Perbedaan Neutrofil pada Kelompok Sevofluran

\begin{tabular}{lccc}
\multicolumn{1}{c}{ Uji Beda } & Mean Difference & t & p \\
\hline Sebelum operasi dengan setelah induksi & 147,8 & 0,28 & 0,77 \\
Sebelum operasi dengan 90 menit setelah inhalasi & 281,3 & 20,6 & 0,001 \\
\hline
\end{tabular}

Keterangan: paired T-test 
Tabel 3 Perbedaan Neutrofil pada Kelompok Halotan

\begin{tabular}{lccc}
\hline \multicolumn{1}{c}{ Uji Beda } & Mean Difference & t & p \\
\hline Sebelum operasi dengan setelah induksi & 152,4 & 0,36 & 0,72 \\
Sebelum operasi dengan 90 menit setelah inhalasi & 274,2 & 7,6 & 0,001 \\
\hline
\end{tabular}

Keterangan: paired T-test

Tabel 4 Perbedaan Efek Sevofluran dengan Halotan terhadap Jumlah Neutrofil

\begin{tabular}{lcccc}
\hline \multicolumn{1}{c}{ Neutrofil } & $\begin{array}{c}\text { Kelompok A } \\
\mathbf{n = 1 8} \\
\text { Mean Difference } \\
\text { ( SB) }\end{array}$ & $\begin{array}{c}\text { Kelompok B } \\
\mathbf{n}=\mathbf{1 8} \\
\text { Mean difference } \\
\text { (SB) }\end{array}$ & t & p \\
\hline Sebelum Operasi dengan setelah induksi & $147,8(76,2)$ & $152,4(87,4)$ & 0,91 & 0,91 \\
Sebelum operasi dengan setelah 90 menit inhalasi & $281,3(93,4)$ & $274,2(95,3)$ & 1,04 & 0,8 \\
\hline
\end{tabular}

Keterangan: T. independent

perbedaan yang bermakna neutrofil rata-rata sebelum operasi antara kelompok sevofluran dan kelompok halotan ( $p>0,05)$. Pada pengamatan setelah induksi dan 90 menit setelah inhalasi juga tidak terdapat perbedaan bermakna antara dua kelompok ( $\mathrm{p}=0,91$; Tabel 4).

\section{Pembahasan}

Penelitian ini mempergunakan agen inhalasi sevofluran dan halotan sebagai maintenance anestesi umum selama pembedahan. Berdasar atas data dasar karakteristik sampel tehadap jenis kelamin, usia, berat badan, dan ASA tidak didapatkan perbedaan yang bermakna antara kedua kelompok. Hal ini menandakan kelompok sevofluran dan halotan layak untuk dibandingkan.

Terdapat penurunan jumlah neutrofil pada kelompok sevofluran. Perbedaan penurunan jumlah neutrofil sebelum operasi dibanding dengan setelah induksi tidak bermakna secara statistika. Namun, penurunan jumlah neutrofil pada 90 menit setelah inhalasi dibanding dengan sebelum anestesi bermakna secara statistika $(p=0,001)$. Penelitian Morisaki $\mathrm{dkk}^{7}$ menunjukkan penurunan neutrofil yang bermakna dalam sirkulasi pada menit ke-20 dengan paparan inhalasi sevofluran. Penelitian lain memperlihatkan penurunan $6 \%$ neutrofil pasien tanpa trauma operasi dan penurunan jumlah ini terjadi karena proses apoptosis neutrofil oleh paparan sevofluran. ${ }^{9}$

Pada kelompok halotan, penurunan jumlah neutrofil setelah intubasi dibanding dengan sebelum operasi secara statistika tidak berbeda bermakna. Namun, penurunan jumlah neutrofil 90 menit setelah inhalasi dibanding dengan sebelum operasi secara statistika bermakna $(p=0,001)$. Penelitian Ahad dkk. ${ }^{10}$ menunjukkan halotan 0,5\% menyebabkan penurunan neutrofil bermakna pascaoperasi pada operasi minor dan mayor. Hal ini disebabkan oleh halotan mendepresi fagositosis secara signifikan. Penelitian ini sesuai dengan penelitian Miwako $^{9}$ yang menunjukkan bahwa halotan menghambat superoksida ion kalsium pada neutrofil dan menghambat mobilisasi kalsium.

Pada uji beda neutrofil antara kelompok sevofluran dan halotan didapat perbedaan yang tidak bermakna pada tiga kali pengukuran. Anestesi inhalasi sevofluran dan halotan selama pembedahan memiliki efek yang tidak berbeda terhadap penurunan jumlah neutrofil. Sesuai dengan penelitian Colucci dkk. ${ }^{11}$ menunjukkan penurunan jumlah neutrofil tidak signifikan pada halotan dan sevofluran 1 MAC selama 2 jam. Hal ini dipengaruhi oleh kosentrasi dan lamanya paparan. ${ }^{11}$ 
Penurunan jumlah neutrofil selalu disertai peningkatan kerentanan terhadap infeksi karena neutrofil berfungsi sebagai fagositosis yang dapat membunuh organisme dan juga mengontrol kontaminasi lokal untuk mencegah infeksi. Neutrofil melepaskan protease elastase dan kolagenase yang berfungsi memperbaiki kerusakan sel, mengubah ekstraseluler, dan membersihkan luka dari sel yang rusak. ${ }^{4}$

\section{Simpulan}

Pada penelitian ini dapat disimpulkan bahwa tidak terdapat perbedaan antara sevofluran dan halotan terhadap penurunan jumlah neutrofil meskipun terjadi penurunan yang setelah 90 menit inhalasi baik pada sevofluran maupun halotan.

\section{Daftar Pustaka}

1. Omera MA. Do volatile inhalation anaesthetics modify the immune response in surgical patients. AJAIC. 2007;9:34-43.

2. Kurosawa S, Masato K. Anesthetics, immune cells and immune response. J Anaesth. 2008;22:263-77.

3. Stevenson GW, Hall SC, Rudnick S, Seleny FL, Stevenson HC. The effect of anaesthetic, agents on human immune response. Anaesthesiology. 2009;72(3):542-52.

4. Malech HL, Gallin JI. Current concepts: immunology neutrophils in human diseases. N Eng J Med. 2010;317(10):687-
90.

5. Tyther R, Halligant M, Wang J, Redmond HP, Shorten G. Effects of chronic occupational exposure to anaesthetics gases on the rate of neutrophil apoptosis among anaesthetists. Eur J Anaesthesiol. 2009;19:604-8.

6. Tyther R, O'Brien J, Wang J, Redmond HP, Shorten G. Effect of sevoflurane on human neutrophil apoptosis. Eur J Anaesthesiol. 2010;20:111-5.

7. Morisaki H, Aoyoma Y, Shimada M, Ochiai $\mathrm{R}$, Takeda J. Leucocyte distribution during sevoflurance anaesthesia. Br J Anaesth. 1997;80:502-3.

8. Shorten J. Potential adverse effect of volatile anaesthetic agents - immune function and chronic occupational exposure. Refresher Courses. Cork: Department of Anaesthesia Cork University Hospital Ireland; 2002.

9. Miwalko N. Inhibition of superoxide production and calcium mobilization in human neutrophils by halothane, enflurance, and isoflurance. Anaesthesiology. 1999;64:4-12.

10. Ahad B, Shah ZA, Mehrajuddin, Shah A, Salahuddin M. Effect of general anaesthesia and surgery on neutrophil phagocytic function. JK-Practioner. 2009;12(3):121-4.

11. Colucci DG, Pulg NR, Hernandez PR. Influence of anaesthetic drugs on immune respon: from inflammation to immunosuppression. OA Anaesthetics. 2013;1(3):21. 